\title{
Comment on 'Ascitic Fluid Analysis in the Differential Diagnosis of Ascites: Focus on Cirrhotic Ascites'
}

\section{Furqan Ahmed* \\ Dow Medical College, Dow University of Health Sciences, Karachi, Pakistan}

*Correspondence to: Furqan Ahmed, Department of Internal Medicine, Dow Medical College, Dow University of Health Sciences, Mission Rd, Karachi 74200 Pakistan. Tel: +92-3142027901, E-mail: furqanka@hotmail.com

First, I would like to congratulate the authors, Huang LL, Xia $\mathrm{HH}$ and $\mathrm{Zhu} \mathrm{SL}$, on the overall great work done in preparing the review article 'Ascitic Fluid Analysis in the Differential Diagnosis of Ascites: Focus on Cirrhotic Ascites'. ${ }^{1}$ However, there seems to be an error in the description of diagnosis of spontaneous bacterial peritonitis (SBP). The authors state "SBP is defined by the presence of neutrophil cells greater than or equal to $250 / \mathrm{mL}$ or a positive bacterial culture in the ascitic fluid without evidence of an abdominal source." The issue here is the fact that the authors make the presence of neutrophil cells greater than or equal to $250 / \mathrm{mL}$ for diagnoses of SBP an option (by using the conjunction term 'or') and not a condition, whereas it is proven by evidence in the literature that it is a prerequisite. ${ }^{2-4}$

Citation of this article: Ahmed F. Comment on 'ascitic fluid analysis in the differential diagnosis of ascites: focus on cirrhotic ascites'. J Clin Transl Hepatol 2017;5(2):184. doi: 10.14218/JCTH.2017.00026.

\section{Conflict of interest}

The author has no conflict of interest related to this publication.

\section{References}

[1] Huang LL, Xia HH, Zhu SL. Ascitic fluid analysis in the differential diagnosis of ascites: focus on cirrhotic ascites. J Clin Transl Hepatol 2014;2:58-64. doi: 10.14218/JCTH.2013.00010.

[2] Velkey B, Vitális E, Vitális Z. Spontaneous bacterial peritonitis. Orv Hetil 2017; 158:50-57. doi: 10.1556/650.2017.30637.

[3] Runyon BA. Management of adult patients with ascites due to cirrhosis: update 2012. Available from: https://www.aasld.org/sites/default/files/guideline_documents/141020_Guideline_Ascites_4UFb_2015.pdf

[4] Skladaný Ľ, Kasová S, Purgelová A, Bystrianska N, Adamcová-Selčanová S. Spontaneous bacterial peritonitis. Klin Mikrobiol Infekc Lek 2016;22:136-140.

The Authors Reply

\section{Lin-Lin Huang ${ }^{1}$, Harry Hua-Xiang $\mathrm{Xia}^{2}$ and Sen-Lin Zhu ${ }^{1 *}$}

${ }^{1}$ Department of Gastroenterology, the First Affiliated Hospital, Sun Yat-sen University, Guangzhou, China; ${ }^{2}$ Novartis Pharmaceuticals Corporation, East Hanover, NJ, USA
*Correspondence to: Sen-Lin Zhu, Department of Gastroenterology, The First Affiliated Hospital, Sun Yat-sen University, 58 Zhongshan $2^{\text {nd }}$ Road, Guangzhou 510080, China. Tel: +86-20-87755766 EXT 8182, E-mail: zhusI@mail.sysu.edu.cn

We are very grateful to Dr. Ahmed for carefully reading our article and kindly providing comments. In response to Dr. Ahmed's question regarding the definition of SBP, we searched and read the relevant literature again. Besides reference $8^{1}$ in our article, reference $53,{ }^{2}$ which provides clinical practice guidelines of the European Association for the Study of the Liver, states "Patients with an ascitic fluid neutrophil count $\geq 250$ cells $/ \mathrm{mm}^{3}$ and negative culture have culture-negative SBP". Also, the literature listed below ${ }^{3-5}$ agree that SBP is defined by the presence of ascitic fluid with neutrophil cells greater than $250 / \mathrm{mm}^{3}$. Thus, based on the literature cited above, the presence of neutrophil cells greater than or equal to $250 / \mathrm{mL}$ alone can establish the diagnosis of SBP. Therefore, we agree with Dr. Ahmed that the presence of neutrophil cells greater than or equal to $250 / \mathrm{mL}$ is a prerequisite, not an option, and the sentence should be corrected as "SBP is defined by the presence of neutrophil cells greater than or equal to $250 / \mathrm{mL}$ without evidence of an abdominal source, and with or without a positive bacterial culture in the ascitic fluid".

\section{Conflict of interest}

The authors have no conflict of interests related to this publication.

\section{References}

[1] Bendtsen F, Grønbaek H, Hansen JB, Aagaard NK, Schmidt L, Møller S. Treatment of ascites and spontaneous bacterial peritonitis - part I. Dan Med J 2012; 59:C4371.

[2] European Association for the Study of the Liver. EASL clinical practice guidelines on the management of ascites, spontaneous bacterial peritonitis, and hepatorenal syndrome in cirrhosis. J Hepatol 2010;53:397-417. doi: 10.1016/ j.jhep.2010.05.004.

[3] Kim JH, Jeon YD, Jung IY, Ahn MY, Ahn HW, Ahn JY, et al. Predictive factors of spontaneous bacterial peritonitis caused by gram-positive bacteria in patients with cirrhosis. Medicine (Baltimore) 2016;95:e3489. doi: 10.1097/MD. 0000000000003489.

[4] Chen CT, Tseng YC, Yang CW, Lin HH, Chen PJ, Huang TY, et al. Increased risks of spontaneous bacterial peritonitis and interstitial lung disease in primary biliary cirrhosis patients with concomitant sjögren syndrome. Medicine (Baltimore) 2016;95:e2537. doi: 10.1097/MD.0000000000002537.

[5] Fernandes SR, Santos P, Fatela N, Baldaia C, Tato Marinho R, Proença H, et al. Ascitic calprotectin is a novel and accurate marker for spontaneous bacterial peritonitis. J Clin Lab Anal 2016;30:1139-1145. doi: 10.1002/jcla. 21994. 